TEME, г. XLI, бр. 4, октобар - децембар 2017, стр. 917-934

Прегледни рад

Примљено: 25. 4. 2017.

DOI: 10.22190/TEME1704917B

Одобрено за штампу: 15. 11. 2017.

\title{
СУДСКА ГРАЪАНСКОПРАВНА ЗАШТИТА ОД ДИСКРИМИНАЦИЈЕ ПО ОСНОВУ ПОЛА
}

\author{
Владимир Боранијашевић \\ Универзитет у Приштини са привременим седиштем у Косовској \\ Митровици, Правни факултет, Косовска Митровица, Србија \\ vladimir.boranijasevic@pr.ac.rs
}

\begin{abstract}
Апстракт
Иако дефинисана као изразито негативна друштвена појава и забрањена одредбама многобројних докумената, дискриминација је у великој мери присутна у савременом друштву. Готово неомеђена листа личних својстава појединаца или групе лица основ је за различите начине и видове дискриминаторског поступања. Један од облика дискриминације је и дискриминација по основу пола. Право на равноправност полова представља једно од основних људских права и значајну вредност демократског друштва, а управо је дискриминација по основу пола један од најзаступљенијих облика дискриминације. У раду је указано на појам равноправности полова, нормативне изворе који забрањују дискриминацију по основу пола и законска решења садржана у Закону о равноправности полова Републике Србије. Посебна пажња посвећена је анализи специфичних правила по којима се пружа грађанскоправна заштита од дискриминације и поступа у парницама за заштиту од дискриминације по основу пола.
\end{abstract}

Кључне речи: дискриминација, равноправност полова, грађанскоправна заштита, парница, терет доказивања.

\section{JUDICIAL CIVIL LEGAL PROTECTION AGAINST DISCRIMINATION BASED ON SEX}

\begin{abstract}
Although defined as an extremely negative social phenomenon and prohibited according to the regulations of numerous documents, discrimination is widely present in contemporary society. An almost unlimited list of personal characteristics of an individual or a group of people is a basis for various ways of discriminatory acts. One form of discrimination is discrimination based on sex. The right to equality of sexes represents one of the basic human rights and a significant value of democratic society, while it is exactly discrimination based on sex that represents one of the most common forms of discrimination. In the paper the concept of equality of sexes, normative sources which prohibit discrimination based on sex and legal solutions contained in the Law on Equality of Sexes of the Republic of Serbia have been pointed out. Special attention has been given to the analysis of the specific rules according to which to provide civil legal protection
\end{abstract}


against discrimination and according to which to act in litigations for protection against discrimination based on sex.

Key words: discrimination, equality of sexes, civil legal protection, litigation, the burden of proof.

\section{УВОД}

Развој модерног демократског друштва условљен је постојањем могућности за једнако и равноправно остваривање зајемчених људских права и, уједно, поштовање различитости појединаца. Без обзира на специфична лична својства и особености, сва лица имају право на једнако уживање људских права и основних слобода. То би значило да у модерном друштву нема дискриминације. Ипак, иако дефинисана као најзначајнија негативна друштвена појава (Петрушић et al., 2012, стр. 8) и основна повреда принципа једнакости (Повереник за заштиту равноправности, 2012, стр. 10), доступни подаци указују на постојање дискриминације у великој мери. Као глобални феномен, дискриминација је распрострањена, за основ има различита лична својства појединаца или група, те на њу треба непрестано указивати и предузимати мере за њено сузбијање. ${ }^{1}$ Ове констатације потврђује и најновији Редован извештај Повереника за заштиту равноправности за 2015. годину, у коме се наводи да је у Републици Србији дискриминација присутна у значајној мери, што се поткрепљује и чињеницом да је у 2015. години Поверенику за заштиту равноправности упућено 20 посто више притужби у односу на 2014. годину. Међутим, како се наглашава у извештају, то не значи да у нашем друштву има више дискриминације у односу на претходне године, већ да је препозната улога институције Повереника за заштиту равноправности у сузбијању дискриминације и да су грађани спремнији да пријаве дискриминацију и затраже заштиту (Повереник за заштиту равноправности, 2016, стр. 5).

Право на равноправност жена и мушкараца представља једно од основних људских права, кључну моралну и правну вредност, подразумевајући равноправну заступљеност, моћ и учешће оба пола у свим сферама друштвеног живота (Пајванчић, Петрушић, 2014, стр. 26). Управо када је у питању равноправност полова, дискриминација је веома заступљена. У поменутом извештају Повереника за заштиту равноправности за 2015. годину закључује се да је Повереник добио највећи број притужби у којима је као основ за дискриминацију био

${ }^{1} \mathrm{O}$ разлозима за постојање дискриминације, мерама и активностима у циљу сузбијања дискриминације видети: Стратегија превенције и заштите од дискриминације, 2013. 
наведен пол као лично својство. Такође, у извештају се наводи да су жене, као и претходних година, у неповољнијем положају у односу на мушкарце у свим областима друштвеног живота (Повереник за заштиту равноправности, 2016, стр. 57). Податке о учесталости дискриминације по основу пола садржи и Редован годишњи извештај Заштитника грађана за 2015. годину (Заштитник грађана, 2016, стр. 106-108).

Један од путева правне заштите од дискриминације по основу пола је и поступак у парницама за заштиту од дискриминације. У раду су анализиране одредбе Закона о равноправности полова Републике Србије којима су прописана правила по којима се пружа грађанскоправна заштита од дискриминације и поступа у парницама за заштиту од дискриминације по основу пола. Посебно је указано на специфична правила поступка којима се одступа од правила опште парничне процедуре са циљем да се дискриминисаном лицу олакша приступ суду и омогући пружање ефикасне правне заштите.

\section{РАВНОПРАВНОСТ ПОЛОВА И ЗАБРАНА ДИСКРИМИНАЦИЈЕ ПО ОСНОВУ ПОЛА}

Равноправност полова је прописана и зајемчена великим бројем међународних и националних правних докумената. Почев од докумената Уједињених нација, преко великог броја докумената Европске уније и Савета Европе, па до Устава Републике Србије и других националних закона, прописана је равноправност жена и мушкараца и забрана дискриминације по основу пола. ${ }^{2}$ Уставом Републике Србије прописано је да држава јемчи равноправност жена и мушкараца и развија политику једнаких могућности (Устав Републике $C p$ бије, 2006, чл. 15). Устав Републике Србије забрањује сваку дискриминацију, непосредну или посредну, по било ком основу, а нарочито по основу расе, пола, националне припадности... (Устав Републике Србије, 2006, чл. 21, ст. 3).

У Републици Србији је 2009. године донет Закон о забрани дискриминачије, који као „кровни” закон представља основ за регулисање забране дискриминације појединаца и појединих друштвених

\footnotetext{
${ }^{2}$ Нпр. Универзална декларација о људским правима, Међународни пакт о граЂанским и политичким правима, многобројне директиве Европске уније, препоруке Савета Европе, документи Организације за европску безбедност и сарадњу (детаљан попис међународних докумената који гарантују равноправност жена и мушкараца и забрањују дискриминацију по основу пола видети код: Пајванчић, Петрушић, Јашаревић, 2010, стр. 20-24, као и на званичном сајту Повереника за заштиту равноправности).
} 
група посебним законима за заштиту од дискриминације. ${ }^{3}$ Након опште дефиниције дискриминације (Закон о забрани дискриминаџије, чл. 2, ст. 1, т. 1. У даљем тексту: 33Д), посебне одредбе о дискриминацији по основу пола налазе се у З3Д у делу који се односи на посебне случајеве дискриминације. Дискриминација по основу пола, према закону, постоји ако се поступа противно начелу равноправности полова, односно начелу поштовања једнаких права и слобода жена и мушкараца у политичком, економском, културном и другом аспекту јавног, професионалног, приватног и породичног живота (З3Д, чл. 20 , ст. 1$){ }^{4}$

Исте године у Републици Србији донет је и Закон о равноправности полова. Под равноправношћу полова подразумева се равноправно учешће жена и мушкараца у свим областима јавног и приватног сектора и сви су дужни да је поштују (Закон о равноправности полова, чл. 2, у даљем тексту: $3 Р П)$.

Дискриминација по основу пола дефинисана је као свако неоправдано прављење разлике или неједнако поступање, односно пропуштање (искључивање, ограничавање или давање првенства) које има за циљ или последицу да лицу или групи отежа, угрози, онемогући или негира признање, уживање или остваривање људских права и слобода у политичкој, економској, друштвеној, културној, грађанској, породичној и другој области (3РП, чл. 4). Надаље, законодавац дефинише непосредну и посредну дискриминацију по основу пола (ЗРП, чл. 5 и 6). У поређењу са општом дефиницијом дискриминације коју предвиђа З3Д, очигледно је да је дата дефиниција дискриминације по основу пола ужа и специфична јер дефинише дискриминацију само по основу једног од могућих основа за дискриминацију. Дефиниција дискриминације по основу пола је, с друге стране, сложена јер обухвата низ елемената: означење начина поступања; циљ поступања; означење субјеката који могу бити дискриминисани и области у којима лица могу бити дискриминисана (Пајванчић et al., 2010, стр. 26-27). Подразумевани елемент дефиниције дискримина-

\footnotetext{
${ }^{3}$ у Републици Србији донети су и Закон о равноправности полова, Закон о спречавању дискриминације особа са инвалидитетом и Закон о заштити лица са менталним сметьама. Одредбама других закона предвиђена је забрана дискриминације у одређеним областима друштвеног живота (детаљну листу закона којима се забрањује дискриминација видети код: Петрушић, Бекер, 2012, стр. 12-13).

${ }^{4}$ Забрањено је ускраћивање права или јавно или прикривено признавање погодности у односу на пол или због промене пола. Забрањено је и физичко и друго насиље, експлоатација, изражавање мржње, омаловажавање, уцењивање и узнемиравање с обзиром на пол, као и јавно заговарање, подржавање и поступање у складу са предрасудама, обичајима и другим друштвеним обрасцима понашања који су засновани на идеји подређености или надређености полова, односно стереотипних улога полова (33Д, чл. 20, ст. 2).
} 
ције је њен основ, у овом случају, пол дискриминисаних лица. Суштински посматрано, начин поступања који се огледа у неоправданом прављењу разлике или неједнаком поступању, односно пропуштању по основу пола, има за циљ отежавање, угрожавање, онемогућавање или негирање признавања, уживања или остваривања људских права и слобода одређеном лицу или групи лица у различитим областима друштвеног живота.

\section{ПОСТУПАК У ПАРНИЦАМА ЗА ЗАШТИТУ ОД ДИСКРИМИНАЦИЈЕ ПО ОСНОВУ ПОЛА}

Један од видова заштите од дискриминације по основу пола је и грађанскоправна заштита. Правила по којима се поступа у парницама за заштиту од дискриминације по основу пола и пружа грађанскоправна заштита дискриминисаном лицу регулисана су одредбама ЗРП. У раду је посебна пажња посвећена специфичним правилима овог поступка којима се одступа од опште парничне процедуре.

У поступку у парницама за заштиту од дискриминације по основу пола, уколико нису предвиђена посебна правила, сходно се примењују одредбе закона којим се уређује парнични поступак (ЗРП, чл. 44).

\section{Проиесна легитимаиија}

Поступак у парницама за заштиту од дискриминације по основу пола може покренути свако лице коме је повређено право или слобода због припадности одређеном полу (ЗРП, чл. 43, ст. 1). Лице које је дискриминисано због полне припадности има активну процесну легитимацију и може својом иницијалном радњом која садржи правозаштитни захтев одређене садржине покренути поступак у парницама за заштиту од дискриминације.

Процесну легитимацију за покретање поступка у парницама за заштиту од дискриминације имају и синдикат и удружења чији су циљеви везани за унапређење равноправности полова. Синдикат или удружење покрећу поступак правне заштите у име дискриминисаног лица, уз његову сагласност. Из овог правила произлази да синдикати и удружења немају активну процесну легитимацију, да поступак покрећу у име дискриминисаног лица и да у парници имају положај заступника тужиоца - лица које је жртва дискриминације (Пајванчић et al., 2010, стр. 110). Међутим, када се ради о дискриминацији којом су повређена права већег броја лица, синдикалне организације и удружења могу покренути поступак у своје име и у том случају имају активну процесну легитимацију. Сматра се да тада ови субјекти не морају да доказују правни интерес за покретање парничног поступка јер им је активна процесна легитимација призната законом, да нису 
дужни да наводе разлоге за покретање поступка и да је сасвим довољна њихова тврдња да је дискриминаторским поступањем повређено право већег броја лица (Пајванчић et al., 2010, стр. 110).

Иако постоји правило да посебни прописи дерогирају опште прописе, када је у питању заштита од дискриминације, сматра се да треба примењивати и тумачити све одредбе антидискриминационих закона (Ђукић, Андрејевић, 2012, стр. 241). У том смислу, процесна легитимација призната је и другим лицима која самостално могу покренути поступак у парницама за заштиту од дискриминације. Према одредбама 33Д, процесну легитимацију имају и Повереник за заштиту равноправности (у даљем тексту: Повереник) и организација која се бави заштитом људских права, односно права одређене групе лица (3ЗД, чл. 46, ст. 1).

Повереник може подићи тужбу за заштиту од дискриминације, осим тужбе за накнаду штете, и то под одређеним условима. Неопходно је да је лице које је дискриминисано поднело притужбу Поверенику. Када се у поступку по притужби утврди да је дошло до дискриминације, Повереник ће подићи тужбу код надлежног суда ако оцени да је то, с обзиром на околности случаја, целисходно ради остваривања делотворне заштите од дискриминације, унапређивања судске праксе у парницама за заштиту од дискриминације, подизања свести јавности и др. (Пословник о раду Повереника за заштиту равноправности, чл. 34, ст. 1). Вођење поступка пред Повереником у коме је утврђено да је дошло до дискриминације услов је за подизање тужбе од стране Повереника, који тужбу подиже у своје име, у јавном интересу. Међутим, није неопходно да је поступак пред Повереником окончан и да је Повереник дао мишљење и препоруку како би лице које је дискриминисано покренуло поступак у парницама за заштиту од дискриминације. Поступак пред Повереником нема карактер претходног поступка, нити његово окончање представља процесну претпоставку за допуштеност пружања правне заштите у парницама за заштиту од дискриминације (Петрушић, 2012а, стр. 917).

Када је дискриминаторским поступањем повређено искључиво једно лице, Повереник може подићи тужбу и покренути поступак за заштиту од дискриминације само уз пристанак тог лица (3ЗД, чл. 46 , ст. 2). ${ }^{5}$ Уколико се ради о дискриминацији групе лица, пристанак за покретање парнице није потребан. ${ }^{6}$

\footnotetext{
${ }^{5}$ Ова посебна процесна претпоставка у погледу покретања поступка тужбом Повереника сасвим је оправдана јер се мора поштовати воља дискриминисаног лица, које ће само проценити да ли је заинтересовано за судску заштиту, иако општи интерес оправдава покретање поступка тужбом Повереника (Петрушић, 2012а, стр. 911).

${ }^{6}$ Тужбу, осим тужбе за накнаду штете, може подићи и лице које се свесно изложило дискриминаторском поступању како би проверило примену правила о забрани дискриминације у конкретном случају (33Д, чл. 46, ст. 3).
} 


\section{Надлежност суда}

Сходно одредби из чл. 22, ст. 2 Закона о уређењу судова Републике Србије, према којој основни суд у првом степену суди у грађанскоправним споровима ако за поједине од њих није надлежан неки други суд, у поступку у парницама за заштиту од дискриминације по основу пола стварно је надлежан основни суд. Могућа је и надлежност вишег суда у првом степену уколико вредност предмета спора омогућава изјављивање ревизије (Закон о уређењу судова, чл. 23, ст. 1, т. 7).

Месна надлежност суда у парницама за заштиту од дискриминације одређена је на специфичан начин. У парницама за остваривање грађанскоправне заштите због дискриминације по основу пола надлежан је суд опште месне надлежности, према закону којим се уређују судови (3РП, чл. 46, ст. 1). Поред суда опште месне надлежности, надлежан је и суд на чијем подручју је седиште, односно пребивалиште тужиоца (3РП, чл. 46, ст. 2). ${ }^{7}$ Законодавац даје могућност дискриминисаном лицу да тужбу подигне не само код суда опште месне надлежности већ и код суда на чијем подручју он као тужилац има седиште, односно пребивалиште. Ради се о изборној месној надлежности која на својеврстан начин привилегује дискриминисано лице и олакшава му приступ суду. Сматра се да се у овом случају као месно надлежан суд може јавити и суд на чијем је подручју извршена штетна радња (Ђукић, Андрејевић, 2012, стр. 243), применом одредбе Закона о парничном поступку, којом је прописано да је у поступку у парницама због повреде права личности, поред суда опште месне надлежности, надлежан и суд на чијем је подручју штетна радња извршена (Закон о парничном поступку, чл. 46, у даљем тексту: 3ПП).

\section{Тужба}

ЗРП прецизно прописује врсте правозаштитних захтева које може истаћи лице дискриминисано по основу пола. Тако свако лице коме је повређено право или слобода због припадности одређеном полу може тужбом покренути поступак у парницама за заштиту од дискриминације по основу пола и од суда захтевати: утврђивање повреде извршене дискриминаторским поступањем; забрану вршења радњи од којих прети повреда; забрану даљег предузимања, односно понављања радњи које су изазвале повреду; стављање ван промета средстава, односно предмета којима је извршена повреда (уџбеници који дискриминаторски или стереотипно представљају пол, штампана

\footnotetext{
${ }^{7}$ Исту формулацију садржи и 33Д, чл. 42.
} 
гласила, рекламни, пропагандни материјал и др.); отклањање повреда и успостављање положаја, односно стања пре извршене повреде и накнаду материјалне и нематеријалне штете (3РП, чл. 43, ст. 1, т. 1-6).

Тужбени захтев у парницама за заштиту од дискриминације по основу пола је или утврђавне или осуђавне природе. Тужбом се тражи утврђивање повреде извршене дискриминаторским поступањем или пак изрицање забране вршења радње од које прети повреда, изрицање забране даљег предузимања, односно понављања радње, стављање ван промета средстава, односно предмета којима је извршена повреда, отклањање повреда и успостављање положаја, односно стања пре извршене повреде и накнада штете. Код утврђавног захтева тражи се утврђивање постојања повреде, те се ради о тужби за позитивно утврђење. Код осталих захтева, тражи се од суда да туженом наложи одређено процесно понашање, да тужени по налогу суда поступа тако што нешто чини, уздржава се од чињења, пропушта или трпи. Појединим од наведених захтева који имају превентивни карактер спречава се дискриминаторско поступање, а другим, који су реститутивне природе, санирају се последице дискриминациje (Пајванчић et al., 2010, стр. 108). Такође, према природи тужбеног захтева, може се извршити и подела тужби на тужбе за пропуштање, тужбе за утврђење дискриминације, тужбе за уклањање стања дискриминације и тужбе за накнаду штете (Водинелић, 2008, стр. 32 42; Ђукић, Андрејевић, 2012, стр. 224-236).

\section{Умешачи}

У поступку у парницама за заштиту од дискриминације по основу пола на страни тужиоца се у својству умешача могу придружити синдикалне организације и удружења чији су циљеви везани за унапређење равноправности полова (3РП, чл. 43, ст. 2). Циљ њиховог придруживања дискриминисаном лицу као тужиоцу је пружање помоћи у постизању успеха у парници, предузимањем радњи у своје име, али у његовом интересу. Пошто ступе у парницу као умешачи, ови субјекти могу о покренутој парници обавестити друга оштећена лица, синдикате и удружења. Чинећи то путем средстава јавног информисања или на неки други погодан начин, поред обавештења о покренутој парници, другим оштећеним лицима, синдикатима и удружењима упућује се позив да се као умешачи или супарничари придруже тужиоцу.

У случају да синдикат или удружење покрећу поступак када је дискриминаторским актом повређено право већег броја лица, лице чије је право повређено може се тужиоцу придружити као умешач (3РП, чл. 43, ст. 3). И када покрећу поступак, ови субјекти могу друга заинтересована лица обавестити о покренутој парници и позвати их да се придруже тужиоцу у већ покренутој парници. 
Нови тужилац ступа у парницу накнадно, уз тужиоца, и то без пристанка туженог који се упустио у расправљање о главној ствари.

\section{Терет доказивања}

Према правилима опште парничне процедуре, терет доказивања је на странци која износи одређену чињеницу за коју сматра да је за њу повољна, те је она и дужна да такву чињеницу докаже. Уколико странка жели да успе у парници, она сноси специфичан процесни терет у погледу изношења доказног материјала и треба да докаже истинитост одређене чињенице (Станковић, 2013, стр. 434).

Међутим, у поступку у парницама за заштиту од дискриминације по основу пола и антидискриминационим парницама уопште, правила о терету доказивања су другачија. Ова специфична правила резултат су примене Директиве 97/80/ЕЦ Савета Европе о терету доказивања у случајевима дискриминације по основу пола. У члану 4 ове директиве прописано је да државе чланице треба да предузму све неопходне мере у складу са својим националним законодавним системима да обезбеде да лица која себе сматрају оштећеним, јер на њих није примењен принцип једнаког поступања, изнесу пред суд или неку другу надлежну институцију чињенице из којих се може претпоставити да се догодила директна или индиректна дискриминација, а да тужени треба да докаже да није дошло до кршења принципа једнаког поступања. Скоро 10 година касније, донета је Директива 2006/54/ЕЦ Европског парламента и Савета о имплементацији принципа једнаких могућности и једнаког поступања према мушкарцима и женама у питањима запошљавања и занимања, која такође садржи овакву одредбу (чл. 19, ст. 1).

У овом поступку терет доказивања је на туженом, ${ }^{9}$ лицу које је извршило дискриминацију, али под одређеним условима. Тачније, уколико тужилац у току поступка учини вероватним да је извршен акт дискриминације по основу пола, терет доказивања да услед тог акта није дошло до повреде начела једнакости, односно начела је-

\footnotetext{
${ }^{8}$ Скоро идентича одредба коју садржи ова директива последица је чињенице да је Директива 97/80/ЕЦ у ствари преиначена у Директиву 2006/54/ЕЦ (Рорив, 2012, стр. 27, фуснота 45).

${ }^{9}$ У литератури се говори и о „подељеном терету доказивања”, а не о пребацивању терета доказивања, у смислу да тужилац доказује да је до дискриминације дошло, а тужени има за задатак да докаже да до дискриминације није дошло (Мешкић, Пурнер, 2013, стр. 55). Надаље, назначене су чињенице које се не морају доказивати, и то: субјективна намера дискриминације, коју је тешко доказати; и правно значење статистика, у смислу да је доказано да се ради о дискриминацији уколико статистике потврђују да је одређена група лица неком мером била погођена у знатно већој мери него друге групе лица (Мешкић, Пурнер, 2013, стр. 56).
} 
днаких права и обавеза, сноси тужени (ЗРП, чл. 49, ст. 2$).{ }^{10}$ У теорији се истиче да су ова посебна правила уведена како би се олакшао положај тужиоца, посебно са аспекта да је изузетно тешко да се са великим степеном извесности докаже да је неједнако поступање засновано на личном својству лица (Петрушић, Бекер, 2012, стр. 52). У суштини, задатак је тужиоца да учини вероватним да је дискриминатор извршио акт дискриминације с обзиром на лично својство одређеног лица или групе лица. Када тужилац успе у томе, терет доказивања прелази на туженог који ће доказивати да својом радњом није прекршио начело једнакости. У зависности од тога да ли је успео или није да то докаже, суд ће утврдити да није прекршено ово начело или да је прекршено и да је до дискриминације дошло. Има мишљења да није прихватљиво сматрати да тужени треба да доказује до нивоа извесности да до повреде није дошло само зато што је тужилац учинио вероватним оно што тврди (Петрушић, 2012б, стр. 270). Такође, принцип пребацивања терета доказивања није апсолутан jep ће терет доказивања поново бити на тужиоцу уколико жели да успе у парници ако тужени чињеницама поткрепљеним доказима чини тужбени захтев неоснованим (Попоска, Михајлоски, Георгиевски, 2013, стр. 41).

И пракса Европског суда за људска права последњих година препознаје специфичности доказивања у антидискриминационим парницама, иако првобитно није било воље да се терет доказивања пребаци на туженог (Рорив, 2012, стр. 30). Принцип пребацивања терета доказивања установљен је у пракси Европског суда правде, најпре у случајевима полне дискриминације, а данас је дубоко укорењен у европском антидискриминационом законодавству (Попоска et al., 2013, стр. 27). Сматра се да постоје два битна разлога која оправдавају пребацивање терета доказивања на туженог, а то су: заштита слабије стране правног односа и осигурање приступа информацијама, у смислу да тужилац има отежан приступ информацијама које су утицале на радњу дискриминације (Родин, 2009, стр. 3).

\section{Привремене мере}

Привремене мере представљају правна средства којима овлашћено лице обезбеђује остварење свог материјалноправног захтева у парничном, ванпарничном или извршном поступку, а њихово дејство огледа се у обезбеђењу једног потраживања у временски ограниченом трајању (Станковић, Боранијашевић, 2014, стр. 285-286). Оне се могу одредити пре покретања судског поступка, у току по-

\footnotetext{
${ }^{10}$ Видети и: 33Д, чл. 45, ст. 2.
} 
ступка и по његовом окончању, све док извршење не буде спроведено, са циљем обезбеђења новчаног или неновчаног потраживања.

Одредбом из чл. 50, ст. 1 ЗРП прописано је да пре покретања или у току поступка у парници за заштиту од дискриминације по основу пола дискриминисано лице, односно субјекти који су овлашћени на покретање поступка, могу захтевати одређивање привремене мере којом се забрањује дискриминаторско поступање до правноснажног окончања поступка. Неопходно је приметити да је ово законско решење корак напред у односу на правила З3Д у погледу привремених мера. Тачније, одредбом из чл. 44, ст. 1 33Д прописано је да тужилац може уз тужбу, у току поступка, као и по окончању поступка, све док извршење не буде спроведено, захтевати да суд привременом мером спречи дискриминаторско поступање ради отклањања опасности од насиља или веће ненакнадиве штете. Карактеристична је чињеница да је законодавац временски ограничио могућност тражења привремене мере ${ }^{11}$ јер тужилац може тражити одређивање привремене мере у тренутку подизања тужбе. Дакле, уз почетну парничну радњу којом покреће поступак. Околност да се привремена мера не може тражити пре покретања судског поступка сматра се сужењем заштите због дискриминације јер и у овим случајевима постоји једнака потреба да се као и иначе интервенише и пре подизања тужбе (Водинелић, 2008, стр. 44). Према ЗРП, одређивање привремене мере може се тражити и пре покретања поступка, а наравно и у току поступка за заштиту од дискриминације по основу пола. Такође, одредба ЗРП говори о дискриминисаном лицу, као тужиоцу, али и о другим субјектима који су овлашћени на покретање поступка, проширујући могућност да и они захтевају одређивање привремених мера.

Дискриминисано лице или субјекти овлашћени за покретање поступка дужни су да у предлогу за издавање привремене мере учине вероватним да постоји конкретна опасност повреде права због дискриминаторског поступања и да би без одређивања привремене мере наступила знатна материјална или нематеријална штета (3РП, чл. 50, ст. 2). Самим тим, у предлогу за одређивање привремене мере наводе се чињенице на којима се заснива са̂м предлог и прилажу докази помоћу којих ће суд моћи да се увери да вероватно постоји потреба да се одреди конкретна мера обезбеђења. Поступак за одређивање привремене мере има карактер самосталног поступка који претходи парници, уколико је одређивање привремене мере затражено пре покретања поступка за заштиту од дискриминације по основу пола. Уколико је одређивање привремене мере затражено у току поступка,

${ }^{11}$ Видети и: Палачковић, 2011, стр. 77. 
поступак за одређивање привремене мере води се као адхезиони поступак уз поступак за заштиту од дискриминације по основу пола.

Уколико суд одреди привремену меру, њена садржина састоји се у забрани дискриминаторског поступања туженом до правноснажног окончања поступка пружања правне заштите од дискриминације (3РП, чл. 50, ст. 1). Суд такође може по службеној дужности одредити привремену меру под условима предвиђеним за одређивање привремене мере на предлог дискриминисаног лица или субјеката овлашћених за покретање поступка (3РП, чл. 50, ст. 4). Жалба на решење о одређивању привремене мере не одлаже извршење решења.

\section{Начело нарочите хитности}

Иако је начело хитности једно од основних процесних начела, оно је у поступку у парницама за заштиту од дискриминације по основу пола посебно наглашено. Како се ради о правозаштитном захтеву који изискује пружање ургентне правне заштите (Пајванчић et al., 2010 , стр. 115), законодавац је прописао да је поступак у парницама за остваривање грађанскоправне заштите од дискриминације по основу пола нарочито хитан (3РП, чл. 47, ст. 1). Нарочита хитност поступка конкретизује се и посебним правилима којима се омогућава временска концентрација поступка, поштовање прописане хитности поступка, а уједно одступа од правила опште парничне процедуре.

Посебна правила о роковима који се односе на одржавање првог рочишта у поступку и одговор на тужбу указују на намеру законодавца да скраћивањем рокова у односу на општа правила парничне процедуре оствари хитност у поступању. Прво рочиште мора се одржати у року од 15 дана од дана пријема тужбе (ЗРП, чл. 47, ст. 2). Логично се надовезује и одредба по којој је рок за одговор на тужбу осам дана (3РП, чл. 47, ст. 2). Од самог подизања тужбе, иако законом то није изричито прописано, захтева се нарочито хитно поступање суда. Наиме, пошто прими тужбу, суд ће је претходно испитати. Уколико утврди да је тужба допуштена, благовремена и формално уредна, суд ће је доставити туженом на одговор. Иако у односу на правила опште парничне процедуре $3 Р П$ не прописује рок у коме се тужба доставља туженом, ${ }^{12}$ суд ће морати хитно да поступа с обзиром на кратак рок за одговор на тужбу и дужност да прво рочиште одржи у року од 15 дана. Пошто достави тужбу туженом са свим прилозима, тужени је дужан да на тужбу одговори у року од осам дана. ${ }^{13}$ Када тужени одговори на тужбу, суд одговор на тужбу

\footnotetext{
${ }^{12}$ Према ЗПП, суд у року од 15 дана од дана пријема тужбе у суд тужбу са свим прилозима доставља туженом на одговор (3ПП, чл. 296, ст. 1).

${ }^{13}$ Према ЗПП, тужени је дужан да поднесе суду одговор на тужбу у року од 30 дана од дана достављања тужбе са прилозима (3ПП, чл. 297, ст. 1).
} 
доставља тужиоцу и заказује прво рочиште. Уколико тужени не одговори на тужбу у предвиђеном року, суд може да донесе пресуду због пропуштања, а ако нема услова за њено доношење, суд ће заказати прво рочиште, које се мора одржати у року од 15 дана од дана пријема тужбе. ${ }^{14}$

Хитност поступка конкретизована је одредбама о роковима када су у питању привремене мере. Иако је можда било логичније да је законодавац одредбе о роковима у погледу привремених мера сместио у део закона који се односи на привремене мере, законодавац је ова правила прописао у делу који се односи на хитност поступка. Чини се и оправдано - како би се на једном месту, у једном члану закона, кроз више одредаба указало на нарочиту хитност поступка која произлази из природе затражене правне заштите. Суд је дужан да одлуку о предлогу за издавање привремене мере донесе у року од три дана од дана пријема предлога (ЗРП, чл. 47, ст. 3). На одлуку суда о предлогу за издавање мере могуће је изјавити приговор. Рок за приговор на одлуку о привременој мери је 48 сати од пријема одлуке, а одлука о приговору доноси се у наредних 48 сати (ЗРП, чл. 47, ст. 4).

Пресуда коју суд доноси у поступку у парницама за заштиту од дискриминације по основу пола може се побијати жалбом. Рок за жалбу је осам дана од дана достављања преписа пресуде (ЗРП, чл. 47, ст. 5), а о изјављеној жалби другостепени суд дужан је да одлучи у року од три месеца од дана њеног изјављивања (ЗРП, чл. 47, ст. 5). ${ }^{15}$ У односу на правила опште парничне процедуре, приметно је да рок од три месеца почиње од дана изјављивања жалбе, а не од тренутка пријема списа од првостепеног суда, како је предвиђено одредбама ЗПП (ЗПП, чл. 383, ст. 2). То практично значи да рок од три месеца обухвата пријем жалбе код првостепеног суда, све радње првостепеног суда у погледу изјављене жалбе, достављање жалбе са свим списима другостепеном суду и све процесне радње другостепеног суда у поступку по жалби. И прописивањем овог рока, законодавац је промовисао начело нарочите хитности које обележава овај поступак.

\footnotetext{
14 Поменута правила се у великој мери разликују од правила предвиђених одредбама ЗПП. Осим рока за одговор на тужбу од 30 дана, ЗПП предвиђа да ће суд заказати и држати припремно рочиште у року од 30 дана од дана достављања тужиоцу одговора на тужбу. Потом, уколико нема одговора на тужбу, а нема ни услова за доношење пресуде због пропуштања, суд припремно рочиште заказује и одржава најкасније у року од 30 дана од дана када је истекао рок за достављање одговора на тужбу (ЗПП, чл. 301).

${ }^{15}$ И на овом месту је очигледно одступање од правила опште парничне процедуре. Рок за жалбу предвиђен одредбама ЗПП је 15 дана (чл. 367, ст. 1). С друге стране, према 3ПП, другостепени суд је дужан да о жалби, уколико не држи расправу, одлучи најкасније у року од девет месеци од пријема списа првостепеног суда (3ПП, чл. 383, ст. 2$)$
} 


\section{Ослобађање од претходног плаћања трошкова поступка}

У поступку у парницама за заштиту од дискриминације по основу пола тужилац је ослобођен претходног плаћања трошкова поступка, који се исплаћују из средстава суда (ЗРП, чл. 48). Само и искључиво тужилац је, по самом закону, ослобођен претходног плаћања трошкова поступка. То значи да тужилац не мора да подноси суду предлог и захтева ослобођење од претходног плаћања трошкова. У том смислу, ни имовно стање тужиоца није пресудно јер се не захтева да није у могућности да сноси трошкове поступка. Одступања од правила опште парничне процедуре су велика. Најпре, према ЗПП, суд ће ослободити од плаћања трошкова поступка „странку” која према свом општем имовном стању није у могућности да сноси те трошкове (3ПП, чл. 168, ст. 1). Користећи термин странка, законодавац ово право признаје и тужиоцу и туженом као странкама у парничном поступку. Било која странка може предлогом захтевати од суда да је ослободи претходног плаћања парничних трошкова уколико према свом имовном стању није у могућности да сноси трошкове поступка. Затим, странке у парничном поступку нису самим законом ослобођене од претходног плаћања трошкова, већ ће суд одлуку о ослобађању од плаћања трошкова донети на предлог странке (3ПП, чл. 169, ст. 1). То значи да заинтересована странка мора првостепеном суду поднети предлог којим захтева ослобађање од претходног плаћања парничних трошкова, да уз предлог наведе чињенице и њих поткрепи доказима којима се оне потврђују. Суд ће, како би одлучио, спровести потребне извиђаје у циљу провере тачности чињеница које се односе на право на ослобађање од претходног плаћања трошкова поступка (Станковић, 2013, стр. 333). Циљ оваквог законодавног решења у ЗРП сигурно је тежња законодавца да се тужиоцу, као дискриминисаном лицу, олакша приступ суду и пружање ефикасне правне заштите.

\section{ЗАКЉУЧАК}

Уопштено посматрано, доношење низа антидискриминационих закона у Републици Србији веома је значајно. Дискриминација представља посебно штетну друштвену појаву и свака законодавна активност на пољу дефинисања различитих облика дискриминације, регулисања забране дискриминације, санкционисања дискриминаторског поступања и прописивања правила по којима се пружа заштита од дискриминације - доприноси реакцији на већ извршену дискриминацију и превенцији дискриминације у различитим областима друштвеног живота. Доношењем Закона о равноправности полова Републике Србије, право на равноправност полова је законом уређено, забрањена је дискриминација заснована на полу, једном од 
могућих личних својстава која могу бити основ за дискриминацију, предвиђене су посебне мере које би требало да допринесу равноправности полова и предвиђена су посебна правила поступка у коме се пружа грађанскоправна заштита лицима која су дискриминисана по основу пола.

У домену грађанскоправне заштите од дискриминације, законодавац је многобројним специфичним правилима по којима се поступа у парницама за заштиту од дискриминације по основу пола покушао да дискриминисаном лицу олакша приступ суду и омогући пружање ефикасне правне заштите. Почев од процесне легитимациje, посебних правила у погледу надлежности суда, врста захтева за пресуду, преко деликатно уређеног терета доказивања и привремених мера, па до спектра правила којима се уређује нарочита хитност у поступању и штити материјални положај дискриминисаног лица, законодавац је одступио од правила опште парничне процедуре и, поштујући природу правозаштитног захтева и потребу за хитним реаговањем, осмислио правила по којима се пружа ефикасна и делотворна правна заштита. Упркос томе, иако доступни подаци указују на пораст дискриминације по основу пола, веома мали број случајева ове врсте дискриминације је добио судски епилог. У том смислу, неопходно је и даље едуковати ширу јавност о дискриминацији, облицима дискриминације, инструментима путем којих се може тражити заштита од ове друштвено неприхватљиве појаве, а истовремено континуирано унапређивати законодавни оквир у овој области. Зато је посебно значајно што је Влада Републике Србије донела Националну стратегију за родну равноправност за период од 2016. до 2020. године, као стратешки документ којим су прописани циљеви и мере у погледу јачања националних механизама за родну равноправност и елиминисање родно засноване дискриминације.

\section{ЛИТЕРАТУРА}

Директива 97/80/Е3 о терету доказивања у случајевима дискриминације по основу пола [Directive 97/80/EC on the Burden of Proof in Cases of Discrimination Based on Sex], (1997), Савет Европе [European Council]. Retrieved from: http://www.equalrightstrust.org/ertdocumentbank//EU\%20Directive\%2097-80ec.pdf, 4. април 2016.

Директива 2006/54/ЕС о имплементацији принципа једнаких могућности и једнаког поступања према мушкарцима и женама у питањима запошљавања и занимања, [Directive 2006/54/EC on the Implementation of the Principle of Equal Opportunities and Equal Treatment of Men and Women in Matters of Employment and Occupation (recast)], (2006), Европски парламент и Савет [European Parliament and the Council]. Retrieved from: http://eurlex.europa.eu/legal-content/EN/TXT/?uri=CELEX\%3A32006L0054, 4. април 2016.

Ђукић, Л., Андрејевић, С. (2012). Поступак у парницама за заштиту од дискриминације [The Procedure in Litigations for Protection against 
Discrimination]. У Н . Петрушић (ур.), Судска грађанскоправна заштита од дискриминаиије [Judicial Civil Legal Protection against Discrimination] (стр. 241-265). Београд: Повереник за заштиту равноправности и Правосудна академија.

Мешкић, 3., Пурнер, С. (2013). Заштита људских права према Европској конвенцији о људским правима [Protection of Human Rights According to the European Convention on Human Rights]. У: Практични увод у европске стандарде против дискриминачије [A Practical Introduction into European Standards against Discrimination]. Београд: ИР3 (Deutsche Stiftung für internationale rechtliche Zusammenarbeit e.V.).

Национална стратегија за родну равноправност за период од 2016. до 2020. године [National Strategy for Gender Equality for the Period from 2016-2020]. Службени гласник РС. Бр. 4 (2016).

Пајванчић, М., Петрушић, Н. (2014). Значај институционалних механизама за остваривање родне равноправности [The Importance of Institutional Mechanisms for Realization of Gender Equality]. Зборник радова Правног факултета y Huиy [Collection of Papers of the Faculty of Law in Niš], бpoj 76, година LIII, 25-44.

Пајванчић, М, Петрушић, Н, Јашаревић, С. (2010). Коментар Закона о равноправности полова [Comment of the Law on Equality of Sexes]. Београд: Центар модерних вештина.

Палачковић, Д., (2011). Антидискриминационе парнице [Antidiscrimination litigations]. У: Исаиловић, 3. (Ур.): Зборник радова „Правни систем и друштвена криза", свеска прва [Collection of Papers "The Legal System and Social Crisis”, Volume I] (63-77). Косовска Митровица: Правни факултет Универзитета у Приштини са привременим седиштем у Косовској Митровици.

Петрушић, Н., Илић, Г., Рељановић, М., Ћирић, Ј., Матић, М., Бекер, К., Ненадић, С., Трнинић, В. (2012). Примена антидискриминационог законодавства и кривичноправна заштита, студија случаја, пракса и препоруке [The Application of Antidiscrimination Legislation and Criminal Legal Protection, a Case Study, the Practice and Recommendations]. Београд: Удружење јавних тужилаца и заменика јавних тужилаца Србије.

Петрушић, Н., Бекер, К. (2012). Практикум за заштиту од дискриминаиије [A Practicum for Protection against Discrimination]. Београд: Партнери за демократске промене Србија.

Петрушић, Н. (2012а). Процесни положај повереника за заштиту равноправности у антидискриминационим парницама [The Process Position of the Commissioner for Protection of Equality in Antidiscrimination Litigations]. Правни живот, 11, 905-922.

Петрушић, Н. (2012б). Терет доказивања [The Burden of Proof]. У Н. Петрушић (Ур.), Судска грађанскоправна заштита од дискриминачије [Judicial Civil Legal Protection against Discrimination] (стр. 266-274). Београд: Повереник за заштиту равноправности и Правосудна академија.

Попоска, Ж., Михајлоски, 3., Георгиевски, А. (2013). Водич за улогата за комисијата на заштита од дискриминачија во судска постапка и преминување на товарот на докажување [The Guide for the Role of the Commission for Protection against Discrimination in Judicial Proceedings and Transferring of the Burden of Proof]. Скопје: ОСЦЕ.

Пословник о раду Повереника за заштиту равноправности [Rules of Procedure of the Commissioner for Protection of Equality], Службени гласник РС. Бр. 34 (2011). 
Повереник за заштиту равноправности [The Commissioner for Protection of Equality]. Н. Петрушић (Ур.), Приручник за борбу против дискриминаиије на раду [The Manual for Fighting against Discrimination at Work]. (2012).

Повереник за заштиту равноправности [The Commissioner for Protection of Equality]. Редован Извештај Повереника за заштиту равноправности за 2015. годину [Regular Reports of the Commissioner for Protection of Equality]. (2016). Retrieved from: http://www.ravnopravnost.gov.rs/rs/извештаји/извештаји, 31. март 2016.

Приручник о европском антидискриминационом праву [The Manual on European Antidiscrimination Law] (2014). Београд: ИР3. Retrieved from: http://fra.europa. eu/sites/default/files/fra_case_law_handbook_sr_0.pdf, 11. април 2016.

Родин, С. (2009). Доказивање дискриминације и терет доказивања у праву Европске уније [Proving Discrimination and the Burden of Proof in the Law of European Union]. Opatija Inter-University Centre of Excellence Working paper WP H 2, 1 6. Retrieved from: http://excellence.com.hr/Opatija/w/wp-content/themes/ec/ working_papers/Rodin_teret_dokaza.pdf, 4. април 2016.

Рорив, И. (2012). Доказивање случајева дискриминаиије, Улога ситуачионог mecmupara [Proving Cases of Discrimination, the Role of Situational Testing]. Београд: Регионални центар за мањине.

Станковић, Г. (2013). Грађанско прочесно право, прва свеска, Парнично прочесно право [Civil Procedural Law, Volume 1, Litigation Procedural Law]. Београд: Мегатренд Универзитет.

Станковић, Г., Боранијашевић, В. (2014). Извршно проиесно право [Executive Procedural Law]. Косовска Митровица: Правни факултет Универзитета у Приштини са привременим седиштем у Косовској Митровици.

Стратегија превенције и заштите од дискриминације [Strategy for Prevention and Protection against Discrimination], Службени гласник РС. Бр. 60 (2013).

Устав Републике Србије [The Constitution of the Republic of Serbia], Службени гласник РС. Бр. 98 (2006).

Водинелић, В., (2008). Тужбе за заштиту од дискриминације [Charges for Protection against Discrimination]. У С. Гајин (Ур.), Антидискриминационо право водич [Antidiscrimiantion Law - a Guidebook] (стр. 2950). Београд: Центар за унапређивање правних студија.

Закон о парничном поступку [The Law on Civil Proceedings], Службени гласник PC. Бр. 72 (2011), 49 (2013) - одлука УС, 74 (2013) - одлука УС, 55 (2014).

Закон о равноправности полова [The Law on Equality of Sexes], Службени гласник РС. Бр. 104 (2009).

Закон о спречавању дискриминације особа са инвалидитетом [The Law on Prevention of Discrimination against People with Disabilities], Службени гласник РС. Бр. 33 (2006), 13 (2016).

Закон о уређењу судова (The Law on Courts), Службени гласник РС. Бр. 116/2008, 104/2009, 101/2010, 31/2011 др. закон, 78/2011 - др. закон, 101/2011 и $101 / 2013$.

Закон о забрани дискриминације [The Law on Prohibition of Discrimination], Службени гласник, РС. Бр. 22 (2009).

Закон о заштити лица са менталним сметњама [The Law on Protection of People with Mental Disabilities], Службени гласник РС. Бр. 45 (2013).

Заштитник грађана [The Ombudsman]. Редован годишњи извештај Заштитника грађана за 2015. gодину [Regular Reports of the Ombudsman for 2015]. (2016). Retrieved from: (http://www.zastitnik.rs/attachments/Godisnji\%20izvestaj\% 20Zastitnika\%20gradjana\%20za\%202015.pdf, 31. март 2016. 


\title{
JUDICIAL CIVIL LEGAL PROTECTION AGAINST DISCRIMINATION BASED ON SEX
}

\author{
Vladimir Boranijašević \\ University of Priština with Temporary Head Office in Kosovska Mitrovica, \\ Faculty of Law, Kosovska Mitrovica, Serbia
}

\begin{abstract}
Summary
Discrimination represents an extremely negative social phenomenon in contemporary society. A large number of personal characteristics of an individual or a group of people can be a base for different ways of discriminatory acts. Sex, as a personal characteristic, is very often a cause of discrimination, while the available data show that discrimination based on sex is one of the most common ways of discrimination.

By passing the Law on Prohibition of Discrimination, as an umbrella law in this area, a series of antidiscrimination laws and establishing the institution of the Commissioner for Protection of Equality, an adequate normative and institutional framework in the domain of protection against discrimination was created in the Republic of Serbia. By accepting the Law on Equality of Sexes of the Republic of Serbia, the right to the equality of sexes is legally defined, discrimination based on sex is forbidden, particular measures which should contribute to the equality of sexes have been defined as well as particular rules of the procedure in which civil legal protection is provided to people discriminated on the grounds of sex.

In the paper, the author has pointed to the concept of the equality of sexes and normative sources which forbid discrimination based on sex, and special attention has been devoted to the analysis of the specific rules of the Law on Equality of Sexes according to which to act in litigations regarding protection against discrimination based on sex. By numerous particular rules, the legislator has tried to enable for a discriminated person an easier access to the court, to realize the time concentration of the procedure and enable providing effective legal protection. The issues related to procedural legitimating have been discussed in the paper; it has been pointed to the rules concerning the authority of the court and kinds of legal suits. Also, the legal solutions regarding the burden of proof and interim measures have been analyzed, as well as a whole spectrum of rules which regulate particular urgency in acting and protect the material conditions of a discriminated person. It has been noted that by respecting the nature of a legal suit and the need for urgent acting, the legislator has considerably stepped away from the rules of the general litigation procedure, this way creating a system of rules according to which to provide effective and efficient legal protection. Despite this fact, although the available data point to an increase in discriminatory actions based on sex, very few cases of this kind have got the court epilogue. Therefore, it is necessary to further educate the general public on discrimination, ways of discrimination and instruments by means of which protection from this socially unacceptable phenomenon can be required.
\end{abstract}

